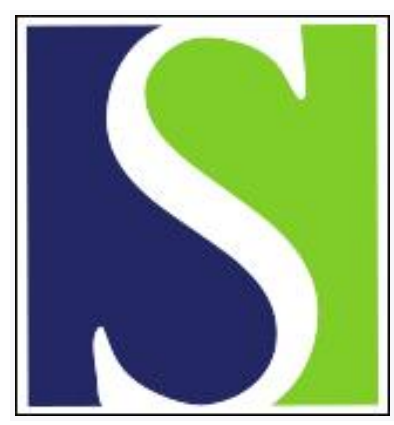

Scand J Work Environ Health 1988;14(1):1-15

https://doi.org/10.5271/sjweh.1958

Issue date: Feb 1988

Respiratory health effects from occupational exposure to wood dusts.

by Goldsmith DF, Shy CM

Affiliation: Department of Internal Medicine, University of California, Davis.

This article in PubMed: www.ncbi.nlm.nih.gov/pubmed/3281247

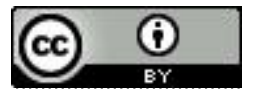




\title{
Respiratory health effects from occupational exposure to wood dusts
}

\author{
by David F Goldsmith, MSPH, PhD, ${ }^{1}$ Carl M Shy, MD, DrPH ${ }^{2}$
}

\begin{abstract}
GOLDSMITH DF, SHY CM. Respiratory health effects from occupational exposure to wood dusts. Scand $J$ Work Environ Health 14 (1988) 1-15. Occupational exposure to wood dusts has been well established as a cause of nasal cancer, dermatitis, and pneumonites from molds growing in wood chips. With the exception of studies on western red cedar asthma, there is a dearth of information on the respiratory toxicity of wood dust exposure. This paper reviews the clinical and epidemiologic literature and identifies the specific woods (with botanical names) and their respiratory disease correlates, including pulmonary function declines, chronic and acute symptoms, and impaired mucociliary transport.
\end{abstract}

Key terms: nasal clearance, pulmonary function, respiratory symptoms, western red cedar asthma, woodworker's asthma.

Hardwood dusts produced in the manufacture of furniture are well established as the cause of excess nasal adenocarcinoma $(1,49)$. Many species of wood, especially exotic hardwoods, have been linked to a variety of dermatoses $(44,75)$. There are also case reports of pneumonitis due to molds found in maple bark $(34,42)$, suberosis $(5,62,74)$, "wood trimmer's disease" (alveolitis) in Scandinavia $(8,67)$, pneumonitis due to molds in wood chips used for fuel (70), and redwood pneumonitis (28). However, with the exception of a chapter in Hausen's monograph (44) and the recently published review (68) by the National Institute for Occupational Safety and Health (NIOSH) there has been no assessment of the clinical and epidemiologic literature of nonmalignant respiratory diseases related to exposure to wood dust.

The lung disease thought to be caused by exposure to wood dust is woodworker's asthma, which, without a thorough work history, may be considered idiopathic by the treating physician. Clinically, this ailment is characterized as an immeriate or delayed hypersensitivity reaction among workers exposed to wood dust, usually hardwoods or exotic timbers. The hypersensitivity response should not be confused with pneumonites due to mold found in tree barks or moldy wood dusts. The clinical literature on woodworker's asthma has focused on a description of the symptoms produced by different types of woods. Most epidemiologic research has concentrated on estimating the

\footnotetext{
1 Toxic Substances Research and Teaching Program and Northern California Occupational Health Center, Department of Internal Medicine, University of California, Davis, CA, United States.

2 Department of Epidemiology, School of Public Health, University of North Carolina, Chapel Hill, NC, United States.
}

Reprint requests to: Dr DF Goldsmith, Northern California Occupational Health Center, LEHR, University of California, Davis, CA 95616, USA. prevalence of respiratory symptoms and describing changes in pulmonary function among workers exposed to western red cedar (Thuja plicata). There have been case reports linking woodworker's asthma to common woods such as oak (Quercus species) and California redwood (Sequoia sempervirens) and to exotic varieties such as teak (Tectonia grandis), cedar of Lebanon (Cedrus libani), iroko (Chlorophora excelsa), ramin (Gonystylus bancanus), American mahogany (Swietenia macrophylla), and abiruana (Lucuma species). Oak, mahogany, abiruana, teak, ramin, and other exotic hardwoods are used in the European and American furniture industry.

This paper describes the extent of risk of nonmalignant respiratory disease from exposure to wood dust. It presents case studies and epidemiologic evidence and a discussion of confounding and bias.

\section{Case studies of woods other than western red cedar}

Table 1 summarizes and provides additional details on the case studies presented in this section. Ordman described a bronchial asthma patient with symptoms of sneezing, runny nose, chest tightness, and wheezing that coincided with the change in types of wood at the plant where the patient worked (59). A skin patch test produced marked reactions to extracts of kejatt, "Congo hardwood" [later identified as Lovoa klaineana (64)], and western red cedar.

Chan-Yeung \& Abboud (20) and doPico (31) described three asthma patients (ex-smokers) who reacted to redwood (Sequoia sempervirens) dust exposure, but who lacked serum antibodies to the wood. Bronchial challenge tests produced immediate and delayed declines in forced expiratory volume in 1 s $\left(\mathrm{FEV}_{1.0}\right)$ (20); however, doPico (31) induced a delayed response only. 
Table 1. Respiratory health effects from case studies of exposure to wood dusts. (FEV ${ }_{1.0}=$ forced expiratory volume in $1 \mathrm{~s}$, FVC = forced vital capacity, RAST = radioallergosorbent test)

\begin{tabular}{|c|c|c|c|c|c|}
\hline Author(s) & Types of wood exposure ${ }^{a}$ & $\begin{array}{l}\text { Number } \\
\text { of cases }\end{array}$ & $\begin{array}{l}\text { Length of } \\
\text { exposure } \\
\text { prior to } \\
\text { symptoms }\end{array}$ & Observed effects & Comments \\
\hline Ordman (59) & $\begin{array}{l}\text { Kejatt (Pterocarpus } \\
\text { angolenis DC), iroko } \\
\text { (Chlorophora excelsa), } \\
\text { partridge or panga-panga } \\
\text { (Milietia stuhimannii), } \\
\text { western red cedar } \\
\text { (Thuja plicata), congo } \\
\text { hardwood (Lovoa klaineana) }\end{array}$ & 1 & 3 months & $\begin{array}{l}\text { Asthma including rhinitis and } \\
\text { dyspnea; confirmed by positive } \\
\text { skin patch tests }\end{array}$ & No smoking data \\
\hline $\begin{array}{l}\text { Chan-Yeung \& } \\
\text { Abboud (20) }\end{array}$ & $\begin{array}{l}\text { California redwood } \\
\text { (Sequoia sempervirens) }^{b}\end{array}$ & 2 & $2-3$ years & $\begin{array}{l}\text { Asthma with dyspnea and } \\
\text { wheezing; confirmed by } \\
\text { immediate, delayed, and dual } \\
\text { decline in FEV }\end{array}$ & $\begin{array}{l}\text { Both ex-smokers; negative skin } \\
\text { patch tests and serum antibody; } \\
\text { chalk and western red cedar } \\
\text { produced no effects }\end{array}$ \\
\hline doPico (31) & $\begin{array}{l}\text { California redwood } \\
\text { (Sequoia sempervirens) }^{\circ}\end{array}$ & 1 & $\sim 3$ months & $\begin{array}{l}\text { Nocturnal tight chestedness } \\
\text { with dyspnea, cough, and } \\
\text { wheeze; confirmed by delayed } \\
\text { decline in } \mathrm{FEV}_{1.0}\end{array}$ & $\begin{array}{l}\text { Ex-smoker; negative skin patch } \\
\text { tests and serum antibody; pine } \\
\text { dust produced no response }\end{array}$ \\
\hline $\begin{array}{l}\text { Sosman } \\
\text { et al (66) }\end{array}$ & $\begin{array}{l}\text { Oak } \\
\text { Mahogany } \\
\text { Cedar }\end{array}$ & $\begin{array}{l}1 \\
1 \\
2\end{array}$ & $\begin{array}{l}12 \text { years } \\
16 \text { years } \\
17-18 \text { years }\end{array}$ & $\begin{array}{l}\text { Asthma with cough, rhinitis, and } \\
\text { dyspnea; confirmed by a decline } \\
\text { in FEV }{ }_{1.0} \text { and FVC (immediate } \\
\text { for oak, dual for mahogany, } \\
\text { delayed for cedar) and positive } \\
\text { serum antibodies for all dusts }\end{array}$ & $\begin{array}{l}\text { No smoking data; negative skin } \\
\text { patch tests; botanical names } \\
\text { missing }\end{array}$ \\
\hline $\begin{array}{l}\text { Greenberg } \\
\text { (41) }\end{array}$ & $\begin{array}{l}\text { Cedar of Lebanon } \\
\text { (Cedrus libani) }\end{array}$ & 6 & 3 months & $\begin{array}{l}\text { Asthma with chest tightness } \\
\text { and rhinitis }\end{array}$ & $\begin{array}{l}\text { Smoking data incomplete; nega- } \\
\text { tive skin patch and serum } \\
\text { antibody tests }\end{array}$ \\
\hline $\begin{array}{l}\text { Pickering } \\
\text { et al (61) }\end{array}$ & $\begin{array}{l}\text { Iroko (Chlorophora exce/sa) } \\
\text { Western red cedar } \\
\text { (Thuja plicata) }\end{array}$ & $\begin{array}{l}1 \\
1\end{array}$ & $\begin{array}{l}1 \text { year } \\
\text { Unknown }\end{array}$ & $\begin{array}{l}\text { Asthma with dyspnea; confirmed } \\
\text { by a positive gradient for the } \\
\text { skin patch tests and positive } \\
\text { serum antibody for iroko only } \\
\text { and a decline in FEV } 1.0 \text { for } \\
\text { both woods }\end{array}$ & $\begin{array}{l}\text { No smoking data; negative } \\
\text { serum antibody and skin patch } \\
\text { tests for cedar }\end{array}$ \\
\hline Eaton (32) & $\begin{array}{l}\text { Cocabolla (Dalbergia } \\
\text { retusa)c }\end{array}$ & 3 & $\begin{array}{l}\text { Days to } 18 \\
\text { months }\end{array}$ & $\begin{array}{l}\text { Upper respiratory irritation; } \\
\text { confirmed by positive skin } \\
\text { patch test in two subjects only }\end{array}$ & $\begin{array}{l}\text { No smoking data or serum } \\
\text { antibody tests }\end{array}$ \\
\hline $\begin{array}{l}\text { Booth et al } \\
\text { (11) }\end{array}$ & Abiruana (Lucuma species) & 2 & $\begin{array}{l}\text { Days to } 1 \\
\text { year }\end{array}$ & $\begin{array}{l}\text { Asthma with nocturnal dyspnea } \\
\text { and cough; confirmed by a } \\
\text { decline in FEV } \text { FV }_{1.0} \text {, FVC, and } \\
\text { maximal midexpiratory flow }\end{array}$ & $\begin{array}{l}\text { Smoking data for only one } \\
\text { subject; positive serum antibody }\end{array}$ \\
\hline $\begin{array}{l}\text { Howie et al } \\
(48)\end{array}$ & $\begin{array}{l}\text { Ramin (Gonystyius } \\
\text { bancanus) }\end{array}$ & 1 & Not stated & $\begin{array}{l}\text { Hypersensitivity with } \\
\text { dyspnea, cough, and sweating; } \\
\text { confirmed by a decline in FEV } \\
\text { and positive serum antibody }\end{array}$ & $\begin{array}{l}\text { Nonsmoker; negative skin patch } \\
\text { tests; by contrast positive serum } \\
\text { antibody not found in eight } \\
\text { asymptomatic co-workers }\end{array}$ \\
\hline $\begin{array}{l}\text { Bush et al } \\
\text { (16) }\end{array}$ & $\begin{array}{l}\text { Zebrawood (Microberlinia } \\
\text { species) }\end{array}$ & 1 & 5 months & $\begin{array}{l}\text { Asthma with cough and dyspnea; } \\
\text { confirmed by a dual decline in } \\
\text { FEV }_{1.0} \text { and positive skin patch, } \\
\text { serum antibody, and RAST tests }\end{array}$ & $\begin{array}{l}\text { No response to control wood } \\
\text { dusts; unexposed referents } \\
\text { showed no reaction to } \\
\text { zebrawood }\end{array}$ \\
\hline $\begin{array}{l}\text { Girard et al } \\
\text { (39) }\end{array}$ & $\begin{array}{l}\text { Plywood } \\
\text { Mahogany (species } \\
\text { unspecified) } \\
\text { Teak (Tectonia grandis) } \\
\text { Okume (Aucoumea } \\
\text { klaineana) }\end{array}$ & $\begin{array}{l}1 \\
1 \\
1 \\
1\end{array}$ & $\begin{array}{l}18 \text { months } \\
4 \text { years } \\
7 \text { months } \\
14 \text { years }\end{array}$ & $\begin{array}{l}\text { Asthma or pneumonitis with } \\
\text { cough, dyspnea, and bronchitis; } \\
\text { confirmed by a decline in FEV } 1.0 \\
\text { and positive skin patch and } \\
\text { serum antibody tests }\end{array}$ & $\begin{array}{l}\text { Last two cases heavy smokers; } \\
\text { smoking data missing on first } \\
\text { two; prevalence survey } \\
\text { indicated } 56 \% \text { of } 96 \\
\text { woodworkers with rhinitis and } \\
17 \% \text { with conjunctivitis }\end{array}$ \\
\hline $\begin{array}{l}\text { Paggiaro } \\
\text { et al (60) }\end{array}$ & $\begin{array}{l}\text { Tanganyika aningre } \\
\text { (Aningeria species) }\end{array}$ & 3 & $\begin{array}{l}\text { Days to } 3 \\
\text { months }\end{array}$ & $\begin{array}{l}\text { Asthma with dyspnea, cough, } \\
\text { and rhinitis; confirmed by } \\
\text { positive skin patch tests and a } \\
\text { decline in FEV } 1.0 \text { in two of three } \\
\text { cases }\end{array}$ & $\begin{array}{l}\text { All three smokers; negative } \\
\text { serum antibody and RAST }\end{array}$ \\
\hline $\begin{array}{l}\text { Bush \& } \\
\text { Clayton (15) }\end{array}$ & $\begin{array}{l}\text { Central American walnut } \\
\text { (Juglans olanchana) }\end{array}$ & 1 & Not stated & $\begin{array}{l}\text { Rhinorrhea, cough, wheezing, } \\
\text { and dyspnea; confirmed by a } \\
\text { decline in } \mathrm{FEV}_{1.0}\end{array}$ & $\begin{array}{l}\text { No smoking data; negative skin } \\
\text { patch test and RAST }\end{array}$ \\
\hline $\begin{array}{l}\text { Innocenti \& } \\
\text { Angotzi }(50)\end{array}$ & $\begin{array}{l}\text { African maple, samba, } \\
\text { obeche (Triplochiton } \\
\text { scleroxylon) }\end{array}$ & 1 & 6 years & $\begin{array}{l}\text { Fever, rhinorrhea, dyspnea; } \\
\text { confirmed by an immediate } \\
\text { decline in } \mathrm{FEV}_{1.0}\end{array}$ & Ex-smoker \\
\hline $\begin{array}{l}\text { Hinojosa } \\
\text { et al (47) }\end{array}$ & $\begin{array}{l}\text { African maple, samba, } \\
\text { obeche (Triplochiton } \\
\text { scleroxylon) }\end{array}$ & 2 & 2 months & $\begin{array}{l}\text { Sneezing, rhinitis, wheezing, } \\
\text { dyspnea, and nasal itching; con- } \\
\text { firmed by positive skin patch } \\
\text { tests and immunoglobulin E and } \\
\text { an immediate decline in FEV } \\
\text { when provoked }\end{array}$ & Both heavy smokers \\
\hline $\begin{array}{l}\text { Hinojosa } \\
\text { et al (46) }\end{array}$ & $\begin{array}{l}\text { African maple, samba, } \\
\text { obeche (Triplochiton } \\
\text { scleroxylon) }\end{array}$ & 4 & 1 to 7 years & $\begin{array}{l}\text { Sneezing, rhinitis, wheezing, } \\
\text { dyspnea, and nasal itching; con- } \\
\text { firmed by positive skin patch } \\
\text { tests and immunoglobulin E and } \\
\text { an immediate decline in } \mathrm{FEV}_{1,0} \\
\text { when provoked }\end{array}$ & $\begin{array}{l}\text { Negative skin patch tests; two } \\
\text { smokers and two nonsmokers; } \\
\text { no response from six referents }\end{array}$ \\
\hline
\end{tabular}

a Botanical names in parentheses.

- Possible reactant: low molecular-weight compounds such as hydroxysugiresinol, sugiresinol, or isoequiric acid.

c Possible reactant: quinones in Dalbergia species? 
Sosman et al (66) described the clinical features of four cases of hypersensitivity to oak, mahogany, or cedar dusts. The patients demonstrated immediate, delayed, and dual responses to the inhalation of dusts (or alcohol extracts) with losses of 20 to $50 \%$ of baseline forced vital capacity (FVC) and $\mathrm{FEV}_{1.0}$.

Greenberg reported on six cases of asthma among workers exposed to dust from cedar of Lebanon (Cedrus libani) (41). The cases presented similar symptoms (chest tightness and cough with occasional sneezing and nasal obstruction), but no antigenantibody precipitations were observed.

Pickering et al (61) reported on a patient with asthma from exposure to iroko (Chlorophora excelsa). Bronchial challenge produced a delayed reaction with a loss of $50 \%$ of the base-line $\mathrm{FEV}_{1.0}$ after $6 \mathrm{~h}$. From skin patch tests, the patient appeared to show a gradient in wheal diameter (from 0.5 to $3.5 \mathrm{~mm}$ ) based on three concentrations of iroko extract.

Eaton (32) presented three cases of respiratory and nasal irritation from exposure to cocabolla (Dalbergia retusa), a tropical hardwood used in England to make pool cues. Two subjects had positive skin patch tests, but pulmonary function and immunologic tests were not done.

Booth et al (11) reported acute pulmonary hypersensitivity with positive skin tests for two workers exposed to abiruana (Lucuma species). When challenged with a $1 \%$ dilution of abiruana dust, an immediate drop in FVC, $\mathrm{FEV}_{1.0}$, and maximum midexpiratory flow (MMF) was observed.

Howie et al (48) presented a case of asthma in which a challenge by ramin dust (Gonystylus bancanus) produced significant losses in $\mathrm{FEV}_{1.0}$.

Bush et al (16) described an asthma patient whose skin patch test, immunoglobulin E (IgE) binding test, and radioallergosorbent test (RAST) were positive for zebrawood (Microberlinia species). After challenge with $1 \%$ zebrawood extract, the patient had a dual response, but no reaction occurred among referents.

Girard et al (39) reported on four asthmatic sanders who responded to dusts from plywood, mahogany, teak (Tectonia grandis), and okume (Aucoumea klaineana). In this prevalence survey of 96 Swiss woodworkers, $56 \%$ had symptoms of rhinitis, $17 \%$ had conjunctivitis, $9 \%$ reported dermatitis, and only $2 \%$ had symptoms of asthma.

Paggiaro et al (60) described three cases of bronchial asthma from exposure to tanganyika aningre (Aningeria species), an African hardwood used in the Italian furniture industry. Intradermal skin tests were positive, and bronchial provocation with tanganyika aningre produced an immediate decline in $\mathrm{FEV}_{1.0}$ in two of the men.

A woodworker handling Central American walnut (Juglans olanchana) developed asthma characterized by rhinitis, wheezing, cough, and dyspnea (15). This reaction was confirmed with an early and late decline in $\mathrm{FEV}_{1.0}$, but the skin patch testing and RAST were both negative.

A case of occupational asthma was reported for an Italian furniture worker exposed to many types of timber (50). Bronchoprovocation with obeche or African maple (Triplochiton scleroxylon) produced an immediate $35 \%$ loss in $\mathrm{FEV}_{1.0}$.

Two Spanish patients developed asthmatic responses to African maple (Triplochiton scleroxylon) dust characterized by cough, sneezing, rhinitis, severe nasal itching, and dyspnea (47), which was confirmed with positive skin patch tests and a positive IgE determination. Four additional asthmatics who worked with obeche and exhibited the same symptoms were examined with the use of skin patch tests, IgE determinations, and bronchial provocation (46). Because two of the four were concomitantly exposed to ramin (Gonystylus bancanus), all four subjects received bronchoprovocation with extracts of both woods. African maple produced an immediate fall in $\mathrm{FEV}_{1.0}$ ranging from 12 to $54 \%$, while ramin produced a decline in $\mathrm{FEV}_{1,0}$ of 11 to $25 \%$ at 100 times the concentration of African maple.

\section{Case studies of western red cedar (Thuja plicata)}

Bridge (13) observed severe nasal symptoms in one woodworker and possible bronchitis in two others exposed to "Canadian red cedar" sawdust. Doig (30) is credited by many investigators with reporting the first case study, in 1940, specifically linking western red cedar (Thuja plicata) with symptoms of asthma. Ordman's patient (59) had a positive intradermal skin test to western red cedar (Thuja plicata). Several Japanese reports from 1960 to 1968 described occupational asthma due to Thuja plicata and Thuja standiski, a Japanese cedar called nezuko (76). They included a case of asthma in a 33-year-old female furniture worker exposed to western red cedar who died after continual attacks of bronchial asthma.

The first thorough description of asthmatic symptoms and diagnostic procedures related to western red cedar exposure (see table 2) was reported in 1970 by three Australian researchers, Gandevia, Milne and Mitchell. In the discussion of their papers $(38,54,55)$, these authors summarized the results of observations on 13 patients. Men without a personal or familial history of allergy or asthma suffered from symptoms in connection with the machining of western red cedar, but they worked problem-free with other woods. Initial complaints were of eye and nasal irritation, advancing to nasal obstruction and cough. The condition increased in severity with loss of exercise tolerance, development of wheezing, breathlessness, and nocturnal cough with phlegm production. The symptoms progressed to chronic asthma and occasionally persisted for several weeks after exposure ended. Smokers 
Table 2. Respiratory health effects from case studies of exposure to western red cedar (Thuja plicata). $\left(F E V_{1.0}=\right.$ forced expiratory volume in $1 \mathrm{~s}, \mathrm{FVC}=$ forced vital capacity)

\begin{tabular}{|c|c|c|c|c|}
\hline Authors & $\begin{array}{l}\text { Number of } \\
\text { cases }\end{array}$ & $\begin{array}{l}\text { Length of exposure } \\
\text { prior to symptoms }\end{array}$ & Observed effects & Comments \\
\hline Milne \& Gandevia (54) & 2 & Days to 1 year & $\begin{array}{l}\text { Western red cedar asthma confirmed } \\
\text { by a decline in FEV } \text { FE }_{1.0} \text { and FVC }\end{array}$ & $\begin{array}{l}\text { Diagnosis not confirmed by } \\
\text { any other tests; smoking } \\
\text { data incomplete }\end{array}$ \\
\hline $\begin{array}{l}\text { Gandevia \& } \\
\text { Milne (38) }\end{array}$ & $\begin{array}{l}6 \\
4\end{array}$ & $\begin{array}{l}8 \text { months to } 8 \text { years } \\
3 \text { weeks to } 2 \text { years } \\
\end{array}$ & $\begin{array}{l}\text { Western red cedar asthma con- } \\
\text { firmed by a decline in FEV } 1.0 \text { and FVC; } \\
\text { rhinitis confirmed by three of four } \\
\text { skin patch tests being positive }\end{array}$ & $\begin{array}{l}\text { Negative skin patch tests; } \\
\text { work histories not } \\
\text { presented }\end{array}$ \\
\hline Mitchell (55) & 1 & 2 years & $\begin{array}{l}\text { Western red cedar asthma confirmed } \\
\text { by a decline in } \mathrm{FEV}_{1.0} \text { and positive } \\
\text { skin patch tests }\end{array}$ & Nonsmoker \\
\hline Chan-Yeung et al (22) & 3 & 1 month to 3 years & $\begin{array}{l}\text { Western red cedar asthma confirmed } \\
\text { by a decline in FEV }{ }_{1.0} \text { (immediate and } \\
\text { delayed) and positive skin patch tests } \\
\text { for two of three subjects }\end{array}$ & $\begin{array}{l}\text { No smoking data; negative } \\
\text { serum antibody test }\end{array}$ \\
\hline Cockcroft et al (25) & 1 & 1 year & $\begin{array}{l}\text { Western red cedar asthma confirmed } \\
\text { by a delayed decline in FEV } \text { F }_{1.0} \text {, a } \\
\text { decline in FVC and maximum } \\
\text { expiratory flow at } 25 \text { and } 50 \% \text { vital } \\
\text { capacity, an increase in closing } \\
\text { capacity, and an increase in nitrogen } \\
\text { washout }\end{array}$ & $\begin{array}{l}\text { Ex-smoker; no effect seen } \\
\text { for spruce dust }\end{array}$ \\
\hline Hamilton et al (43) & 1 & Days & $\begin{array}{l}\text { Western red cedar asthma confirmed } \\
\text { by a dual decline in } \mathrm{FEV}_{1.0}\end{array}$ & Ex-smoker \\
\hline Blainey et al (10) & 2 & $\begin{array}{l}9 \text { months for both } \\
\text { patients }\end{array}$ & $\begin{array}{l}\text { Western red cedar asthma confirmed } \\
\text { by a late decline in FEV }{ }_{1.0} \text { and } \\
\text { maximum expiratory flow at } 50 \% \text { of } \\
\text { vital capacity, and a late nasal } \\
\text { airways resistance in one subject }\end{array}$ & $\begin{array}{l}\text { No smoking information; no } \\
\text { reactions to other wood } \\
\text { dusts (pine, beech, obeche, } \\
\text { deal) or lactose powder }\end{array}$ \\
\hline Cockcroft et al (26) & 2 & Not stated & $\begin{array}{l}\text { Western red cedar asthma (nocturnal) } \\
\text { confirmed by a dual decline in } \mathrm{FEV}_{1.0}\end{array}$ & $\begin{array}{l}\text { Ex-smoker and nonsmoker; } \\
\text { negative skin patch tests }\end{array}$ \\
\hline
\end{tabular}

and nonsmokers were affected, although smoking status was generally overlooked in these early studies.

Bronchial challenge tests with western red cedar dust and extracts of the dust showed immediate, delayed, and dual hypersensitivity response patterns. These responses were characterized by either a precipitous drop in $\mathrm{FEV}_{1.0}$ and/or FVC within $45 \mathrm{~min}$ after inhalation (immediate) or a severe pulmonary function deterioration up to $24 \mathrm{~h}$ after exposure (delayed) or both reactions. In the authors' judgment, these severe responses were the best means to establish a diagnosis of western red cedar asthma $(38,54,55)$.

Six additional papers, three from Canada $(22,25$, 26), two from England $(10,61)$, and one from Australia (43), described ten additional cases of western red cedar asthma. When patients were challenged with aerosols of western red cedar, the reported symptoms were the same as in the Australian cases, and pulmonary function declines confirmed the diagnoses.

The effects of wood dust on lung function or on the development of asthmatic symptoms are usually described in case reports. The case reports summarized in tables 1 and 2 aid in the development of new hypotheses to be tested in epidemiologic studies. However, the lack of a comparison or reference group makes it difficult to draw conclusions on the underlying prevalence of illnesses associated with wood dust. Case studies generally provide a range of clinical impressions concerning symptoms, but they rarely address confounding effects such as smoking. Furthermore, case studies contain little exposure data other than a list of employment in a woodworking occupation and thus are uninformative regarding the extent of hazard.

\section{Epidemiologic studies of woods other than western red cedar}

The epidemiologic findings of respiratory health effects among woodworkers exposed to woods other than western red cedar have been summarized in table 3 .

A 1976 NIOSH survey of a lumber mill in Washington state produced two studies examining symptom prevalence among workers exposed to Douglas fir (Pseudotsuga menziesii), alder (Alnus oregona), and hemlock (Tsuga heterophylla) $(14,33)$. Both studies indicated that $13.5 \%$ of western red cedar shake-mill workers had symptoms of woodworker's asthma in comparison to $5.2 \%$ in the lumber mill and $0 \%$ among the office personnel (see the last entry in table 4). From the industrial hygiene survey the prevalence of woodworker's asthma showed a positive association with dustiness based on cedar concentrations but not on concentrations of other woods in the lumber mill. Occupational rhinitis and chronic bronchitis were much more prevalent among the shake-mill and lumber-mill workers than among the office personnel. Overall, the prevalence of total respiratory disease symptoms among the workers in the shake mill $(40.5 \%)$ and lumber mill $(37.9 \%)$ was over twice that among the office workers $(16.0 \%)$. Only among 
Table 3. Epidemiologic studies of respiratory health effects among woodworkers exposed to woods other than western red cedar. $\left(F E V V_{10}=\right.$ forced expiratory volume in $1 \mathrm{~s}, \mathrm{FVC}=$ forced vital capacity, $\mathrm{FEV} \%=\left(100 \times \mathrm{FEV}_{1.0}\right) / \mathrm{FVC}, \mathrm{K}_{\mathrm{co}}=\mathrm{carbon}$ monoxide diffusion, $\mathrm{MEF}_{50}=$ maximum expiratory flow at $50 \%$ of the $\mathrm{FVC}, \mathrm{MMF}=$ maximum midexpiratory flow, $\mathrm{TL}_{c o}=$ single breath lung transfer factor for carbon monoxide)

\begin{tabular}{|c|c|c|c|c|c|}
\hline Author(s) & $\begin{array}{l}\text { Types of wood } \\
\text { exposure }\end{array}$ & $\begin{array}{c}\text { Number and source } \\
\text { of case or exposed } \\
\text { group }\end{array}$ & $\begin{array}{l}\text { Number and source } \\
\text { of reference group }\end{array}$ & $\begin{array}{l}\text { Measure of effect } \\
\text { and risk level }\end{array}$ & Comments \\
\hline $\begin{array}{l}\text { Brooks et al } \\
\text { (14), Edwards } \\
\text { et al (33) }\end{array}$ & $\begin{array}{l}\text { Hemlock (Tsuga } \\
\text { heterophylla), } \\
\text { Douglas fir } \\
\text { (Pseudotsuga } \\
\text { menziesii), alder } \\
\text { (Alnus oregona) }\end{array}$ & $\begin{array}{l}58 \text { workers in a } \\
\text { lumber mill }\end{array}$ & $\begin{array}{l}25 \text { unexposed } \\
\text { office workers; no } \\
\text { airborne samples } \\
\text { collected }\end{array}$ & $\begin{array}{l}\text { Prevalence ratios for } \\
\text { lumber-mill workers } \\
\text { versus unexposed } \\
\text { workers: thinitis } 5.6 \text {, } \\
\text { bronchitis } 2.8 \text {, all } \\
\text { respiratory symptoms } 2.4\end{array}$ & $\begin{array}{l}\text { No association with } \\
\text { FEV }{ }_{10 \text { or with years }} \\
\text { employed; possible } \\
\text { misclassification of } \\
\text { exposure due to } \\
\text { internal migration }\end{array}$ \\
\hline \multirow[t]{2}{*}{$\begin{array}{l}\text { Al Zuhair } \\
\text { et al (2) }\end{array}$} & $\begin{array}{l}\text { Chipboard and } \\
\text { veneers (species } \\
\text { unknown) }\end{array}$ & $\begin{array}{l}53 \text { workers at a } \\
\text { particle board and } \\
\text { veneer plant (plant 1) }\end{array}$ & \multirow[t]{2}{*}{$\begin{array}{l}52 \text { employees of } \\
\text { inoperative power } \\
\text { plant; no airborne } \\
\text { samples collected }\end{array}$} & $\begin{array}{l}\text { Decline in FVC over a } \\
\text { shift }(P<0.05)\end{array}$ & $\begin{array}{l}\text { No difference in } \\
\text { symptoms, but no } \\
\text { data provided; } \\
\text { finish workers not } \\
\text { analyzed separately }\end{array}$ \\
\hline & $\begin{array}{l}\text { Limba (Termenalia } \\
\text { superba), beech } \\
\text { (Fagus sylvatica), ash } \\
\text { (Fraxis excelsior), } \\
\text { mahogany (species } \\
\text { not specified) }\end{array}$ & $\begin{array}{l}60 \text { machine and } \\
\text { cabinet shop } \\
\text { workers and } 11 \\
\text { office workers } \\
\text { (plant 2) }\end{array}$ & & $\begin{array}{l}\text { Declines in base-line } \\
\text { FEV }_{10}(P<0.001) \text { and } \\
\text { FVC }^{\prime}(P<0.01)\end{array}$ & \\
\hline \multirow[t]{2}{*}{$\begin{array}{l}\text { Whitehead } \\
\text { et al (71) }\end{array}$} & Pine & $\begin{array}{l}220 \text { pine furniture } \\
\text { workers }\end{array}$ & \multirow{2}{*}{$\begin{array}{l}\text { Compared high, } \\
\text { medium, and high } \\
\text { medium with low } \\
\text { dust exposure } \\
\text { levels }\end{array}$} & \multirow{2}{*}{$\begin{array}{l}\mathrm{FEV}_{1.0} \text { and MMF declined } \\
\text { (for young males) among } \\
\text { highly exposed smokers } \\
\text { and nonsmokers; MMF } \\
\text { and FVC declined } \\
\text { ( } P<0.05 \text { ) among highly } \\
\text { exposed smokers and } \\
\text { nonsmokers; MMF showed } \\
\text { log odds ratios of about } 2 \\
\text { for hardwood and pine } \\
\text { workers }(P<0.02 \text { ) }\end{array}$} & \multirow{2}{*}{$\begin{array}{l}\text { No evaluation of } \\
\text { symptoms; overused } \\
\text { FEV } / \text { FVC as } \\
\text { measure of group } \\
\text { response }\end{array}$} \\
\hline & $\begin{array}{l}\text { Hardwood (mostly } \\
\text { hardrock maple, } \\
\text { Acer saccharum) }\end{array}$ & $\begin{array}{l}354 \text { hardwood } \\
\text { furniture makers }\end{array}$ & & & \\
\hline $\begin{array}{l}\text { Beckman } \\
\text { et al (7) }\end{array}$ & Pine & $\begin{array}{l}238 \text { pine furniture } \\
\text { workers [same } \\
\text { source as in the } \\
\text { Whitehead et al (71) } \\
\text { investigation] }\end{array}$ & $\begin{array}{l}\text { Compared subjects } \\
\text { having symptom } \\
\text { complex (low } \\
\text { pulmonary function } \\
\text { or chronic cough } \\
\text { or chronic phlegm) } \\
\text { with normals (using } \\
\text { logistic regression) }\end{array}$ & $\begin{array}{l}\text { Sex, age, and smoking } \\
\text { fit the best model to } \\
\text { symptom complex } \\
\text { (significance } 0.08> \\
\alpha \geq 0.001 \text { ); no effect for } \\
\text { accumulated pine wood } \\
\text { dust exposure }\end{array}$ & $\begin{array}{l}\text { More appropriate } \\
\text { methodology than } \\
\text { in the Whitehead } \\
\text { et al }(71) \text { investiga- } \\
\text { tion }\end{array}$ \\
\hline $\begin{array}{l}\text { Hedenstierna } \\
\text { et al (45) }\end{array}$ & Pine & $\begin{array}{l}48 \text { Swedish sawmill } \\
\text { workers exposed to } \\
\text { terpenes; assumed } \\
\text { to be exposed to } \\
\text { pine dust }\end{array}$ & $\begin{array}{l}47 \text { workers } \\
\text { unexposed to } \\
\text { terpenes; both the } \\
\text { exposed and } \\
\text { reference groups } \\
\text { compared to } \\
\text { external pulmonary } \\
\text { function values }\end{array}$ & $\begin{array}{l}\text { Prevalence of mouth-throat } \\
\text { symptoms greater among } \\
\text { exposed smokers } \\
\text { ( } P<0.05) \text {; among non- } \\
\text { smokers greater prevalence } \\
\text { of following symptoms: } \\
\text { mouth-throat (P }<0.01 \text { ), } \\
\text { chest oppression } \\
\text { (P<0.001), morning } \\
\text { cough }(\mathrm{P}<0.01) \text {, cough } \\
\text { during day (P }<0.05) \text {; } \\
\text { among exposed workers } \\
\text { base-line FEV } \\
\text { (P }<0.05 \text { ) and phase } \\
\text { III \% } \mathrm{N}_{2} / 1 \text { increased } \\
(\mathrm{P}<0.01)\end{array}$ & $\begin{array}{l}\text { Not adjusted for } \\
\text { age or sex; did not } \\
\text { directly compare } \\
\text { exposed workers } \\
\text { and referents with } \\
\text { robust methods }\end{array}$ \\
\hline Goldsmith $(40)$ & $\begin{array}{l}\text { White oak (Quercus } \\
\text { species), mahogany } \\
\text { (Swietenia macro- } \\
\text { phylla), andiroba } \\
\text { (Carapa species), } \\
\text { poplar (Liriodendron } \\
\text { tulipifera), walnut } \\
\text { (Juglans nigra) }\end{array}$ & $\begin{array}{l}55 \text { sanders and } \\
\text { cutters from a } \\
\text { North Carolina } \\
\text { furniture plant }\end{array}$ & $\begin{array}{l}23 \text { finish workers } \\
\text { and } 16 \text { workers } \\
\text { unexposed to } \\
\text { wood dust or } \\
\text { finishing work }\end{array}$ & $\begin{array}{l}\text { Frequent sneezing, odds } \\
\text { ratio } 4.0(P=0.030) \text {; eye } \\
\text { irritation, odds ratio } 4.1 \\
(P=0.049) \text {; stepwise re- } \\
\text { gression for base-line } \\
\text { peak flow and cumulative } \\
\text { employment in dusty jobs } \\
(P=0.0345) ; \text { stepwise } \\
\text { regression for postshift } \\
\text { peak flow and fraction of } \\
\text { particulate }<10 \mu \mathrm{m} \text { in } \\
\text { size }(P=0.0272)\end{array}$ & $\begin{array}{l}\text { Overall study power } \\
\text { low for detecting } \\
\text { symptom differences; } \\
\text { lack of personal } \\
\text { exposure data (only } \\
\text { area samples) }\end{array}$ \\
\hline $\begin{array}{l}\text { Carosso } \\
\text { et al (17) }\end{array}$ & $\begin{array}{l}\text { Assumed to be } \\
\text { hardwoods }\end{array}$ & $\begin{array}{l}55 \text { asymptomatic } \\
\text { exposed workers }(A) \text {, } \\
15 \text { exposed workers } \\
\text { with cough and } \\
\text { dyspnea }\left(B_{1}\right), 20 \\
\text { exposed workers } \\
\text { with dyspnea and } \\
\text { bronchial hyperacti. } \\
\text { vity }\left(B_{2}\right)\end{array}$ & $\begin{array}{l}53 \text { laboratory } \\
\text { employees (C) }\end{array}$ & 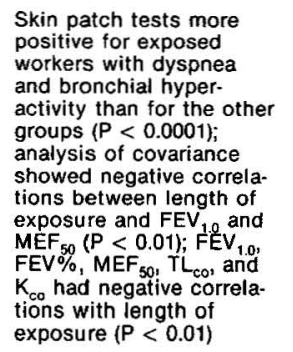 & $\begin{array}{l}\text { Exposure levels for } \\
\text { specific woods (or } \\
\text { botanical names) not } \\
\text { given; subjects } \\
\text { assumed to be alt } \\
\text { men }\end{array}$ \\
\hline
\end{tabular}

a Botanical names in parentheses. 
shake-mill workers exposed to western red cedar was a significant $(\mathrm{P}<0.001)$ decline in $\mathrm{FEV}_{1.0}$ detected during a shift (14), a finding not unexpected given the known effects of Thuja plicata. However, assuming migration between mills, one cannot attribute chronic symptom effects to each wood dust exposure or type of mill. Furthermore, the prevalence data were unadjusted for possible confounding by age, smoking, prior exposures, and social class.

Al Zuhair et al (2) compared pulmonary function during the workshift among British workers from two furniture plants with employees of an inoperative power station (referents). The workers were exposed to dusts from chipboard, unspecified veneers, limba (Terminalia superba), beech (Fagus sylvatica), ash (Fraxinus excelsior), mahogany (species unspecified), oak (Quercus species), and ramin (Gonystylus bancanus). The authors reported that no differences in respiratory symptoms were found; however, no symptom data were provided. The level of $\mathrm{FEV}_{1.0}$ and FVC among the machine and cabinet shop workers (including 11 office workers) in the second furniture plant showed greater mean declines in pulmonary function than the power-plant employees although the utility workers were older by 8 to 10 years. No doseresponse associations were observed between loss of pulmonary function and dust level, although workers exposed to the highest dust levels in the second plant tended to show the greatest decline in $\mathrm{FEV}_{1.0}$ and FVC. However, exposure to finishes was not analyzed separately, base-line pulmonary function values were not provided or analyzed, no dust samples were obtained at the power plant (reference), and no details were provided on the symptom prevalence among the woodworkers.

Whitehead et al (71) conducted a prevalence study of respiratory function among 354 hardwood (mostly Acer saccharum maple) and 220 pine furniture workers. The average dust exposure in the department where the subjects worked was multiplied by the number of years employed in that work area and summed to provide low, medium, and high categories of life-time dust exposure. The authors sought trends in mean pulmonary function levels categorizing their findings by smoking status, age, sex, and type of wood. Overall, no clear correlations were seen for the hardwood workers, although the FVC, $\mathrm{FEV}_{1.0}$, and MMF rate ${ }^{3}$ declined for current smokers at higher exposure levels among those older than 35 years of age.

The investigators next developed prediction equations for the pulmonary function values based on age, height, and sex. Among the workers exposed to hardwood dust, FVC showed inverse associations (lowest ratio of pulmonary function compared to predicted in the highest exposure category) for smokers

\footnotetext{
3 The authors reported that the MMF rate was reduced among the ex-smokers only (and omitted mention of FVC and $\mathrm{FEV}_{1.0}$ ), but the published data are as described here.
}

and nonsmokers. Similar results were observed for MMF among the smokers and ex-smokers. Among the present smokers and ex-smokers exposed to pine, inverse associations were observed for $\mathrm{FEV}_{1.0}$. MMF produced a clearer trend among ex-smokers and never smokers than among current smokers (71).

The authors classified the subjects as low or normal on whether their observed pulmonary function value fell below the lower fifth percentile of healthy nonsmokers. Among both types of woodworkers, only MMF showed statistically significant odds ratios of about 2.1 ( $\mathrm{P}<0.02)$, smoking having been adjusted for. Whitehead et al have suggested that measurable effects exist for wood dust exposure among pine and hardwood furniture makers. However, given the large number of comparisons, the small numbers of subjects in the low pulmonary function categories, and the lack of responses among nonsmokers, the authors' interpretations are difficult to accept.

Beckman et al (7) examined 238 pine furniture workers from Whitehead et al's study using logistic regression with maximum likelihood estimation. The outcome variable, respiratory dysfunction, was defined as decreased $F E V_{1.0}$ (less than the fifth percentile of normals) or positive response to questions about chronic cough or chronic phlegm on a questionnaire. Sex, age, and smoking were significantly correlated with respiratory dysfunction, but no effect was discerned for years of exposure to pine wood dust. These results are contrary to Whitehead et al's (71) for pine workers. However, the findings seem more plausible because the methodology used by Beckman et al appears to be more appropriate and robust for the continuous data than the categorical stratified approach used by Whitehead et al (71).

Hedenstierna and his colleagues (45) examined the pulmonary symptoms, spirometry and nitrogen $\left(\mathrm{N}_{2}\right)$ washout of 48 Swedish sawmill workers exposed to pine (terpenes) and 46 unexposed sawmill workers. The dust concentrations averaged $0.85 \mathrm{mg} / \mathrm{m}^{3}$, while the mean terpene level was $254 \mathrm{mg} / \mathrm{m}^{3}$. (Terpene levels had increased two- to threefold during the previous five years; historical dust concentrations were not presented.) Among the smokers only mouth-throat symptoms were significantly greater among the exposed workers than among the referents. Among the nonsmoking workers, those exposed to terpenes had significantly greater risk of the following symptoms: mouth-throat irritation, chest oppression (tightness), morning cough, and cough during the day, although there was no adjustment for age or sex. Among 24 exposed nonsmokers, there was a significant base-line decrement of 0.311 in $\mathrm{FEV}_{1.0}$ compared to external reference values when adjusted for age, sex, and height; closing volume and phase III $\% \mathrm{~N}_{2} / \mathrm{l}$ were significantly higher in the exposed nonsmokers. These risks were not found among the referents, regardless of smoking status. When duration of employment was examined with linear regression, only phase III was sig- 
nificant among the exposed smokers, whereas among the nonsmoking exposed millworkers there was no significant correlation between lung function and duration of employment. There were no acute changes in pulmonary function in a comparison of Monday morning (base line) values with Wednesday or Thursday afternoon values. It is unclear why the authors did not compare exposed workers directly with referents and did not use more robust methods such as multivariate regression. Although the current mean pine dust levels were low, it may be possible that base-line pulmonary function could have been a function of historically higher wood dust concentrations. However, because the research was on current terpene exposure, and not on wood dust per se, the relevance to pine dust exposure may be limited.

In 1984 Goldsmith (40) presented the first epidemiologic study of the hardwood furniture industry in southeastern United States. The author compared symptom responses and pulmonary function among the following three groups of furniture workers: those exposed to wood dust [55 sanders and cutters working mostly with oak (Quercus species), mahogany (Swietenia macrophylla), andiroba (Carapa species), poplar (Liriodendron tulipifera), and walnut (Juglans nigra)]; those exposed to finishes (23 workers); and those exposed to neither wood dust nor finishes (16 workers). With the use of logistic regression and adjustment for age, sex, and pack-years, none of the chronic pulmonary disease symptoms or asthma conditions were significantly correlated with exposure to wood dust; the only exceptions were positive responses to acute symptom questions asking if subjects had eye irritation or frequent sneezing while at work. These two replies were significantly $(P<0.05)$ correlated with wood dust exposure with odds ratios of 4.0. Using multivariate regression analysis, the author found no significant associations between base-line pulmonary function and dust or finish variables after adjusting for age, sex, height, and smoking (factors that explained 50 to $70 \%$ of the variance). The exception was peak flow, which had a significant correlation $(\mathrm{P}<$ 0.05 ) with cumulative employment in wood dust jobs. Change in FVC over the workshift was correlated with finishing jobs after adjustment for age, daily smoking level, mass median particle diameter, and geometric mean $(P=0.0203)$. Difference in peak flow was significantly correlated with the fraction of particulates $<10 \mu \mathrm{m}$ in size, after adjustment for age, daily smoking habit, and mean dust levels $(P=0.0272)$. Except for the correlation between change in peak flow and dust concentrations (particulates $<10 \mu \mathrm{m}$ ), there were no significant associations between wood dust levels and pulmonary function measured in the baseline examination or during the workshift. There were no interactions between smoking and either dust or finish exposure, and both may have been a result of the lack of personal dust sampling data or of low study power for the analysis of symptoms.
Carosso et al (17) compared pulmonary function and skin patch tests in three groups of Italian furniture workers and a reference group of laboratory workers. The woodworkers were administered symptom questionnaires, and on this basis were grouped as follows: group A - 55 exposed asymptomatic workers; group $B_{1}-15$ exposed workers with chronic cough and dyspnea on exertion; and group $B_{2}-20$ workers with dyspnea and bronchial hyperreactivity. Group C consisted of 52 employees from the investigators' laboratory staff. Group $\mathbf{B}_{2}$ showed greater skin reaction than the other groups, although reactivity to specific woods was presented unclearly. After adjusting for age, height, weight, and smoking habits in a multivariate regression, the authors found that $\mathrm{FEV}_{1.0}, \mathrm{FVC}$, $\mathrm{FEV} \%\left[\left(100 \times \mathrm{FEV}_{1.0}\right) / \mathrm{FVC}\right]$, and maximum expiratory flow at $50 \%$ of the FVC $\left(\mathrm{MEF}_{50}\right)$ were significantly $(\mathrm{P}<0.05)$ lower in the $\mathrm{B}_{1}$ group than in the other groups. The same results were observed for the single breath lung transfer factor for carbon monoxide $\left(\mathrm{TL}_{\mathrm{CO}}\right)$ and carbon monoxide diffusion $\left(\mathrm{K}_{\mathrm{CO}}\right)$, but not for alveolar volume. In addition, the means for $\mathrm{FEV} \%, \mathrm{MEF}_{50}$, and $\mathrm{K}_{\mathrm{CO}}$ were in the opposite direction, and $\mathrm{FEV}_{1.0}$ showed the following trend: $\mathrm{B}_{1}<\mathrm{B}_{2}<\mathrm{A}<\mathrm{C}$. The means for $\mathrm{TL}_{\mathrm{CO}}$ were in the opposite direction. The authors examined duration of exposure to wood dust using the analysis of covariance and showed a significant $(P<0.01)$ negative correlation for length of exposure versus $\mathrm{FEV}_{1.0}$ and $\mathrm{MEF}_{50}$. The findings for $\mathrm{FEV}_{1.0}, \mathrm{FEV} \%$, $\mathrm{MEF}_{50}, \mathrm{TL}_{\mathrm{CO}}$, and $\mathrm{K}_{\mathrm{CO}}$ were significant for the duration of wood dust exposure and for the square of the duration of exposure. Although this paper has some drawbacks (lack of exposure data and types of woods), it suggests that wood dust exposure is strongly correlated with chronic obstructive lung disease among asthmatics. Furthermore, impaired pulmonary function was demonstrated in both symptomatic and asymptomatic woodworkers in a comparison with referents. The authors also showed that there was a significant reduction in $\mathrm{K}_{\mathrm{CO}}$, the $\mathrm{K}_{\mathrm{CO}}$ of the asthmatics being lower than that of the healthy exposed workers and that of the healthy exposed workers being lower than that of the referents. Carosso et al ascribed the findings either to reduced capillary blood volume due to vasoconstrictive extractives in the wood dust or to a thickening of alveolar capillaries as a result of allergic responses.

\section{Epidemiologic studies of western red cedar}

Table 4 provides a summary of the epidemiologic studies of western red cedar asthma. Gandevia (37) studied 30 men highly exposed to western red cedar and 17 men with minimal or no exposure to the dust in the same Australian plant from which two cases of asthma came $(38,54)$. An association was found 
Table 4. Epidemiologic studies of respiratory health effects among woodworkers exposed to western red cedar (Thuja plicata). $\left(\mathrm{FEV}_{10}=\right.$ forced expiratory volume in $1 \mathrm{~s}$, Gaw $/ \mathrm{Vtg}=$ ratio of the reciprocal of airway resistance to thoracic gas volume, FVC $=$ forced vital capacity, MMF = maximum midexpiratory flow, V60 \% TLC $=60 \%$ of the maximum total lung capacity)

\begin{tabular}{|c|c|c|c|c|}
\hline Author(s) & $\begin{array}{c}\text { Number and source } \\
\text { of case or } \\
\text { exposed group }\end{array}$ & $\begin{array}{l}\text { Number and source } \\
\text { of reference group }\end{array}$ & $\begin{array}{l}\text { Measure of effect } \\
\text { and risk level }\end{array}$ & Comments \\
\hline Gandevia (37) & $\begin{array}{l}30 \text { highly exposed } \\
\text { workers }\end{array}$ & $\begin{array}{l}17 \text { workers with low } \\
\text { or no exposure }\end{array}$ & $\begin{array}{l}\text { Mean daily decline in FEV } \\
\text { and FVC greater in highly } \\
\text { exposed workers, regardless of } \\
\text { smoking status }(P<0.025)\end{array}$ & $\begin{array}{l}\text { Unadjusted for height and age; } \\
\text { misclassification of exposure } \\
\text { and pulmonary function tracings } \\
\text { lessen confidence in results }\end{array}$ \\
\hline Ishizaki et al (51) & $\begin{array}{l}1320 \text { Japanese } \\
\text { furniture workers, } \\
25 \text { asthmatic } \\
\text { responders skin } \\
\text { patch tested with } \\
10 \% \text { western red } \\
\text { cedar extract }\end{array}$ & $\begin{array}{l}20 \text { asthmatic } \\
\text { nonresponders } \\
\text { [spruce (Picea species), } \\
\text { lauan (Sharea species)] }\end{array}$ & $\begin{array}{l}\text { Overall prevalence of asthma } \\
4.5 \% \text {, rhinitis } 9.5 \% \text {, hives } \\
3.6 \% \text {, dermatitis } 4.6 \% \text {, and } \\
\text { conjunctivitis } 9.5 \% \text {; highest } \\
\text { prevalence in processing area }\end{array}$ & $\begin{array}{l}\text { Pulmonary function not reported; } \\
\text { no healthy referents examined; } \\
\text { dermal responses only at a } 10 \% \\
\text { concentration of western red } \\
\text { cedar; no effects for reference } \\
\text { dusts }\end{array}$ \\
\hline Mue et al (58) & $\begin{array}{l}17 \text { woodworkers } \\
\text { identified from a } \\
\text { questionnaire and } \\
\text { confirmed by clinical } \\
\text { examination }\end{array}$ & $\begin{array}{l}22 \text { asthma patients, } \\
22 \text { healthy referents }\end{array}$ & $\begin{array}{l}\text { Odds ratio for positive skin } \\
\text { patch tests } 13.8 \text { in comparison } \\
\text { of woodworkers with both } \\
\text { reference groups combined; } \\
50 \% \text { of woodworkers had a } \\
\text { greater than } 20 \% \text { decline in } \\
\text { FEV }{ }_{10} \text { and maxirnum expiratory } \\
\text { flow at } 50 \% \text { of vital capacity } \\
\text { versus } 0 \% \text { among } 25 \text { referents }\end{array}$ & $\begin{array}{l}\text { No smoking data collected; also } \\
\text { positive response in } 13 \text { of } 16 \\
\text { cases using Prausnitz-Kustner } \\
\text { test }\end{array}$ \\
\hline $\begin{array}{l}\text { Chang-Yeung } \\
\text { et al (23) }\end{array}$ & $\begin{array}{l}22 \text { patients with } \\
\text { asthma from western } \\
\text { red cedar }\end{array}$ & $\begin{array}{l}2 \text { healthy volunteers, } \\
4 \text { bronchitics, } \\
4 \text { asthmatics }\end{array}$ & $\begin{array}{l}82 \text { and } 0 \% \text { of cases and } \\
\text { referents, respectively, reacted } \\
\text { to brunchial challenge with a } \\
\text { decline in } \mathrm{FEV}_{1.0}\end{array}$ & $\begin{array}{l}\text { No serum antibodies found; skin } \\
\text { patch tests produced mild } \\
\text { responses to plicatic acid; no } \\
\text { response to reference wood; } \\
\text { validated response to plicatic } \\
\text { acid; greatest response seen } \\
\text { in V60\% TLC and Gaw/Vtg }\end{array}$ \\
\hline Chang-Yeung (18) & $\begin{array}{l}16 \text { responders to } \\
\text { western red cedar }\end{array}$ & $\begin{array}{l}10 \text { referents [Douglas } \\
\text { fir (Pseudotsuga men- } \\
\text { ziesii)] }\end{array}$ & $\begin{array}{l}100 \text { and } 0 \% \text { of the cases and } \\
\text { referents, respectively, responded } \\
\text { to plicatic acid }\end{array}$ & $\begin{array}{l}\text { No serum antibodies found; } \\
\text { skin patch tests produced mild } \\
\text { responses to plicatic acid; no } \\
\text { response to reference wood; } \\
\text { validated response to plicatic } \\
\text { acid; greatest response seen in } \\
\text { V60\% TLC and Gaw } / V t g\end{array}$ \\
\hline $\begin{array}{l}\text { Chang-Yeung } \\
\text { (21), Ashley et ai } \\
\text { (4) }\end{array}$ & $\begin{array}{l}405 \text { cedar mill } \\
\text { workers }\end{array}$ & $\begin{array}{l}220 \text { mill workers } \\
\text { unexposed to } \\
\text { western red cedar, } \\
82 \text { ex-cedar mill } \\
\text { workers }\end{array}$ & $\begin{array}{l}\text { Prevalence ratios for western red } \\
\text { cedar workers versus unexposed } \\
\text { workers (adjusted for age and } \\
\text { smoking): breathlessness } 2.3 \\
(P=0.0002) \text {, rhinitis } 1.6(P= \\
0.04) \text {, cough } 2.0(P=0.005), \\
\text { phlegm } 2.4(P=0.002) \text {, wheeze } \\
1.8(P=0.07) \text {, conjunctivitis } 1.8 \\
(P=0.11) \text {; overall prevalence of } \\
\text { western red cedar asthma } 1.1 \text { to } \\
4.9 \% \text {; MMF greater among } \\
\text { workers exposed to western } \\
\text { red cedar than among the } \\
\text { referents }(P<0.0001)\end{array}$ & $\begin{array}{l}\text { Nonparticipants in study } \\
\text { not surveyed to determine if } \\
\text { they differed from the volunteers; } \\
\text { no evidence of deterioration } \\
\text { in pulmonary function over a } \\
\text { week; data suggest possible } \\
\text { synergy between exposure to } \\
\text { western red cedar and smoking }\end{array}$ \\
\hline $\begin{array}{l}\text { Brooks et al (14), } \\
\text { Edwards et al (33) }\end{array}$ & $\begin{array}{l}74 \text { workers in a red } \\
\text { cedar shake mil! }\end{array}$ & $\begin{array}{l}25 \text { unexposed office } \\
\text { workers }\end{array}$ & $\begin{array}{l}\text { Asthma associated with } \\
\text { dustiness; prevalence for } \\
\text { western red cedar exposure } \\
\text { versus nonexposure: rhinitis } \\
12.8 \text {, bronchitis } 2.4 \text {, and all } \\
\text { respiratory symptoms } 2.5 \text {; decline } \\
\text { in FEV } \text { F }_{1.0} \text { over shift }(P<0.001)\end{array}$ & $\begin{array}{l}\text { Likely to have been other wood } \\
\text { dust exposures due to internal } \\
\text { migration; results unadjusted } \\
\text { for age, smoking, or social class }\end{array}$ \\
\hline
\end{tabular}

a Type of reference wood in brackets.

between rhinitis and asthma (all among nonsmokers) and work in jobs with high exposure to western red cedar (table 4). Among highly exposed red cedar workers, there was a decline in $\mathrm{FEV}_{1.0}$ and FVC regardless of smoking status $(\mathrm{P}<0.025)$, although the author noted that interobserver errors may have occurred in the grading of pulmonary function tracings. Gandevia expected greater declines in the heavily exposed workers, and he concluded that western red cedar is not a general bronchoconstrictor, such as was observed in the case studies of Gandevia \& Milne (38), Milne \& Gandevia (54), and Mitchell (55).

Ishizaki et al (51) conducted a study of red cedar asthma among 1320 furniture workers in Kanuma, Tochigi Prefecture, Japan. The prevalence of asthma and rhinitis was highest in the processing work area (exposure assumed to be sanding and assembly), and conjunctivitis symptoms were greatest in sawing. Of the 60 identified asthma patients, $42 \%$ were sensitive to cedar dust in intradermal tests. This paper is difficult to interpret because attention is so heavily focused on the 60 asthma patients, only 26 of whom reacted positively to the inhalation of red cedar dust, and there was no adjustment for atopic status. Inhalation of cedar dust produced inconsistent pulmonary function findings and, given the lack of healthy referents, the authors' interpretation that the skin test results confirm atopic response to western red cedar is not supported. There was no discussion of the confounding effects of age, sex, and smoking on symptoms, and 
some computational errors hampered the interpretation of the results.

Mue et al (58) studied 17 asthmatic framemakers, 12 asthma patients, and 22 healthy referents and contrasted their dermatologic and respiratory responses to red cedar extracts. The cedar fraction saturated 30 to $60 \%$ with ammonium sulfate was the most sensitive. Sixteen of 17 patients had positive skin reactions compared with only three of 44 referents; $50 \%$ of the cedar asthma patients had a greater than $20 \%$ loss of $\mathrm{FEV}_{1.0}$ and a decline in $\mathrm{MEF}_{50}$ in comparison to none of the referents. The researchers also induced $100 \%$ mortality from anaphylatic shock among guinea pigs sensitized to the same fraction of western red cedar. It was unclear why the extract required the ammonium sulfate, why only half of the original patients were studied, and why smoking was not controlled.

Chan-Yeung and her colleagues $(18,23)$ presented a pair of benchmark papers on western red cedar asthma. (See the fourth entry in table 4.) The authors studied 22 British Columbian woodworkers who had respiratory symptoms and were occupationally exposed to red cedar. The subjects' responses were compared to those of a reference group, none of whom gave a history of exposure to western red cedar. Eighteen of the $22(82 \%)$ woodworkers reacted to the red cedar extract with an immediate, late, or dual loss of $\mathrm{FEV}_{1.0}$ or FVC, while none of the referents responded to the bronchial challenge. Douglas fir (Pseudotsuga manziessii) extract (used as a control dust) produced an insignificant decline in $\mathrm{FEV}_{1.0}$ after provocation.

To analyze further the components of asthmatic responses produced by western red cedar, the authors prepared a dialyzed extract of cedar dust (23). This extract contained high molecular-weight substances and was administered to three responders without reaction. A second fraction, containing the nonvolatile components of cedar extract, was tested on two woodworkers and produced parallel declines in pulmonary function. Since plicatic acid is the largest proportion of the nonvolatile fraction, it alone was tested at half strength on 16 patients and on all the referents. Four immediate reactions, five late responses, and seven dual reactions were recorded along with the expected symptoms; no referents reacted to the nonvolatile extract. After recovery, four woodworkers were challenged again with the same dose of plicatic acid. The late asthmatic responses occurred earlier, and symptoms were more severe and more prolonged (23).

Chan-Yeung and her colleagues concluded that skin tests were of no value in diagnosis; bronchial challenge yielding early, late, or dual declines in $\mathrm{FEV}_{1.0}$ was judged to be the best method of diagnosing western red cedar asthma (23). Plicatic acid, the major nonvolatile component of red cedar extract $(40 \%$ by weight) was judged to be the etiologic agent causing the western red cedar asthma syndrome. The authors concluded that the asthmatic responders were allergic to plicatic acid although the immunologic mechanisms remained to be determined. [Evans \& Nicholls (35) subsequently demonstrated that red cedar has the same capacity as cotton dust to trigger histamine release in pig and human lung in vitro.] The paper of ChanYeung et al is important because of its demonstration of etiologic activity by plicatic acid in responders but not in referents (23).

In a companion article, Chan-Yeung (18) determined which measurements of airway response provided the best indicators of bronchoconstriction. She reported that the greatest response was seen in $60 \%$ of the maximum total lung capacity (V60\% TLC), declining 60 and $80 \%$ during initial and delayed reactions, respectively. The ratio of $\mathrm{Gaw} / \mathrm{Vtg}^{4}$ also declined precipitously in both immediate and late responders. The levels of reduction in the maximal expiratory flow volume curves depended on the severity of the bronchoconstriction.

Chan-Yeung and her colleagues (21) next conducted a prevalence study comparing 405 red cedar workers with two groups of reference workers, 220 sawmill workers never exposed to western red cedar, and 82 ex-cedar sawmill workers now working in British Columbian mills cutting other timbers (21). Adjusting for age and smoking, the authors reported prevalence ratios of about 2.0 for breathlessness, rhinitis, cough, phlegm, wheeze, and conjunctivitis when the western red cedar workers were compared to the noncedar exposed referents. Respiratory symptoms were greater among the ever-smoking exposed workers than among the nonsmoking exposed men, a finding suggesting synergism between the two factors. Although the prevalence of western red cedar asthma was $1.1 \%$ among the exposed workers, the authors estimated the prevalence for ever-exposed workers to be about 4 to $5 \%$ on the basis of the $4.9 \%$ prevalence among excedar workers. The higher symptom prevalence in the former group in comparison to that of currently exposed workers suggests that sensitized individuals tend to migrate to jobs where there is no exposure to irritating cedar dust. Thus, it is logical that workers remaining in cedar mills are a selected group that tolerates cedar dust exposure.

A companion article reported that there was little daily change in lung function and no evidence of deterioration in pulmonary function over the week (4). When the data were stratified on duration of dust exposure, greater lung function decline was observed among current smokers when the cedar workers were compared to referents. With the use of linear regression and stratification on duration of employment, the decline in MMF was greater in cedar workers than in unexposed workers among both the smokers and nonsmokers (4).

\footnotetext{
4 These measures are obtained on a body plethysmograph that determines airway resistance (Raw), its reciprocal (Gaw), and thoracic gas volume (Vtg).
} 
Table 5. Epidemiologic studies of nasal symptoms among woodworkers. (FEV $\mathrm{F}_{1.0}=$ forced expiratory volume in $1 \mathrm{~s}$ )

\begin{tabular}{|c|c|c|c|c|c|}
\hline Author(s) & $\begin{array}{l}\text { Types of wood } \\
\text { exposure }\end{array}$ & $\begin{array}{c}\text { Number and source } \\
\text { of case or exposed } \\
\text { group }\end{array}$ & $\begin{array}{l}\text { Number and source } \\
\text { of reference group }\end{array}$ & $\begin{array}{l}\text { Measure of effect } \\
\text { and risk level }\end{array}$ & Comments \\
\hline Black et al (9) & $\begin{array}{l}\text { Assumed to be } \\
\text { hardwoods such as } \\
\text { beech, oak, and } \\
\text { mahogany }\end{array}$ & $\begin{array}{l}9 \text { furniture workers } \\
\text { from High Wycombe } \\
\text { in the United } \\
\text { Kingdom }\end{array}$ & $\begin{array}{l}12 \text { nonwoodworkers, } \\
\text { mostly researchers } \\
\text { from an atomic } \\
\text { energy plant }\end{array}$ & $\begin{array}{l}\text { Referents' nasal clearance } \\
6.8 \text { (range } 1.9-18.5 \text { ) } \\
\text { mm/min; only two } \\
\text { exposed subjects had } \\
\text { measurable clearance; } \\
\text { rest classified as having } \\
\text { mucociliary stasis }\end{array}$ & $\begin{array}{l}\text { One snuff user from } \\
\text { exposed group } \\
\text { should have been } \\
\text { excluded; some } \\
\text { dysplasia observed } \\
\text { in the cytologic } \\
\text { examinations of the } \\
\text { woodworkers' nasal } \\
\text { mucosa }\end{array}$ \\
\hline $\begin{array}{l}\text { Andersen } \\
\text { et al (3) }\end{array}$ & $\begin{array}{l}\text { In order of quantity } \\
\text { used: teak (Tectonia } \\
\text { grandis), oak (Quer- } \\
\text { cus species), chip- } \\
\text { board, rosewood } \\
\text { (Dalbergia nigra), } \\
\text { mahogany (species } \\
\text { unspecified), jako- } \\
\text { randa (Machaerium } \\
\text { species), beech } \\
\text { (Fagus sy/vatica), } \\
\text { ramin (Gonystylus } \\
\text { bancanus), motine } \\
\text { (Guibourtia arnol- } \\
\text { diana), masonite, pine } \\
\text { (species unspecified) }\end{array}$ & $\begin{array}{l}43 \text { furniture workers } \\
\text { exposed to wood } \\
\text { dust concentrations } \\
\text { of }>5 \mathrm{mg} / \mathrm{m}^{3}\end{array}$ & $\begin{array}{l}25 \text { furniture workers } \\
\text { exposed to wood } \\
\text { dust concentrations } \\
\text { of }<5 \mathrm{mg} / \mathrm{m}^{3}\end{array}$ & $\begin{array}{l}\text { Higher exposed workers } \\
\text { had excess symptoms } \\
\text { of middle ear inflamma- } \\
\text { tion, sinusitis, prolonged } \\
\text { colds, asthma, bloody } \\
\text { nose, and rhinitis (signi- } \\
\text { ficant but no P-value } \\
\text { given); proportion of } \\
\text { mucostatics increased as } \\
\text { dust level (over five } \\
\text { levels) increased } \\
\text { (significant, but no } \\
\text { P-value given) }\end{array}$ & $\begin{array}{l}\text { Over a weekend } \\
\text { two-thirds of a } \\
\text { sample recovered } \\
\text { normal nasal } \\
\text { clearance; FEV }{ }_{1.0} \text { or } \\
\text { forced expiratory } \\
\text { flow at } 25-75 \% \text { of } \\
\text { the forced vital } \\
\text { capacity did not } \\
\text { correlate with the } \\
\text { dust levels }\end{array}$ \\
\hline $\begin{array}{l}\text { Boysen \& } \\
\text { Solberg (12) }\end{array}$ & $\begin{array}{l}\text { Teak (Tectonia } \\
\text { grandis), mahogany } \\
\text { (species unspecified), } \\
\text { bibo, ramin (Go- } \\
\text { nystylus bancanus), } \\
\text { koto (Pterygota } \\
\text { macrocarpa), oak } \\
\text { (Quercus species), } \\
\text { beech (Fagus syiva- } \\
\text { tica), chipboard } \\
\text { (from pine and } \\
\text { spruce) }\end{array}$ & $\begin{array}{l}113 \text { Norwegian } \\
\text { furniture workers } \\
\text { from five well- } \\
\text { established plants } \\
\text { and employed at } \\
\text { least six years }\end{array}$ & $\begin{array}{l}54 \text { nonfurniture } \\
\text { workers employed in } \\
\text { chemical industry, } \\
12 \text { otolaryngological } \\
\text { patients, and } 18 \\
\text { workers from a } \\
\text { hospital }\end{array}$ & $\begin{array}{l}\text { Prevalence ratios for } \\
\text { symptoms: nasal obstruc- } \\
\text { tion } 4.0(P<0.05) \text {, allergy } \\
2.0 \text {, and rhinitis } 3.7 \\
(P<0.05) \text {; histological } \\
\text { score of nasal dysplasia } \\
\left.\text { correlated ( } R^{2}=0.16\right) \\
\text { with nasal stenosis } \\
(P<0.001) \text { and number } \\
\text { of years from first job } \\
(P<0.001)\end{array}$ & $\begin{array}{l}\text { Exposure to hard } \\
\text { and soft woods } \\
\text { significant } \\
(P<0.05) \text { only in } \\
\text { simple correlation }\end{array}$ \\
\hline $\begin{array}{l}\text { Withemsson \& } \\
\text { Lundh (73) }\end{array}$ & $\begin{array}{l}\text { Assumed to be } \\
\text { hardwoods }\end{array}$ & $\begin{array}{l}45 \text { Swedish furniture } \\
\text { and flooring } \\
\text { workers from six } \\
\text { plants; employed } \\
\text { average of } 15 \text { years } \\
\text { with wood dust } \\
\text { exposure of } \\
2.0 \mathrm{mg} / \mathrm{m}^{3}\end{array}$ & $\begin{array}{l}17 \text { staff members } \\
\text { from Department of } \\
\text { Otolaryngology at } \\
\text { the University } \\
\text { Hospital of } \\
\text { Huddinge }\end{array}$ & $\begin{array}{l}\text { Prevalence ratios: } \\
\text { columnar epithelium } 0.76 \\
(P<0.05) \text {, ciliated } \\
\text { columnar epithelium } 0.57 \\
\text { (P<0.05), goblet cell } \\
\text { hyperplasia } 5.50, \text { meta. } \\
\text { plastic epithelium } 1.60 \text {, } \\
\text { and metaplastic cuboidal } \\
\text { epithelium } 2.42(P<0.05 \text { ) }\end{array}$ & $\begin{array}{l}\text { No association } \\
\text { between rhino- } \\
\text { scopic and histologic } \\
\text { findings; identifica- } \\
\text { tion of wood species } \\
\text { could have aided } \\
\text { specificity }\end{array}$ \\
\hline $\begin{array}{l}\text { Wilhemsson } \\
\text { et al (72) }\end{array}$ & $\begin{array}{l}\text { Assumed to be } \\
\text { hardwoods }\end{array}$ & $\begin{array}{l}22 \text { cases of } \\
\text { ethmoidal } \\
\text { adenocarcinoma } \\
\text { among Swedish } \\
\text { wood workers } \\
\text { employed from } \\
18 \text { to } 55 \text { years }\end{array}$ & None & $\begin{array}{l}86 \% \text { (19 of } 22) \text { had } \\
\text { cuboidal metaplasia; } 69 \% \\
\text { (16 of } 22 \text { ) had dysplasia }\end{array}$ & $\begin{array}{l}\text { A reference group } \\
\text { needed; tobacco } \\
\text { habits not reported }\end{array}$ \\
\hline
\end{tabular}

a Botanical names in parentheses.

In 1977, Chan-Yeung conducted a follow-up study of 38 patients who had western red cedar asthma and had been unexposed for an average of 1.5 years (19). Of the group, $27(71 \%)$ became asymptomatic and $11(29 \%)$ had continued pulmonary symptoms. Of the latter subgroup, eight patients had recurrent bouts of asthma that coincided with upper respiratory infections or exposure to auto exhaust, cigarette smoke, or cold weather. The author could not determine whether bronchial hyperreactivity is the predisposing factor in western red cedar asthma or the result of the condition (19).

Ten years later Chan-Yeung and her colleagues (24) extended the follow-up to include 232 patients diagnosed with western red cedar asthma and traced their clinical status over an average of four years. There were four groups of patients studied: group 1 unexposed to red cedar and asymptomatic, group 2 unexposed to cedar and with symptoms, group 3 working with red cedar daily, and group 4 working with cedar intermittently. There were no significant differences in age, height, sex, or smoking habits between the groups. Atopic individuals were more likely to be in the exposed groups than in the unexposed ones. When examined, the patients in group 1 had significantly higher $\mathrm{FEV}_{1.0}, \mathrm{FVC}$, and forced expiratory flow at $25-75 \%$ of the forced vital capacity $\left(\mathrm{FEF}_{25-75}\right)$ than the subjects in group 2 . The provocative concentration of methacholine was higher among the asymptomatic patients than among those with symptoms of asthma and thus indicated that the asymptomatic group was diagnosed at an earlier stage. The authors suggested that early diagnosis and removal from exposure will benefit occupational asthma patients, particularly those with a confirmed diagnosis of western red cedar asthma. 


\section{Studies of sinonasal health effects}

To examine early precursors of nasal cancer, investigations of nasal clearance and examinations of nasal mucosa were carried out in Great Britain, Denmark, Norway, and Sweden. The results of these investigations have been summarized in table 5. Black et al (9) studied mucociliary clearance in British furniture workers by blowing a microdrop of ${ }^{99 \mathrm{~m}} \mathrm{Tc}$-labeled styrene particles in saline into the subjects' nasal mucosa. The nasal clearance of 12 referents, mostly researchers at an atomic energy facility, was compared to that of nine furniture workers from High Wycombe. The referents' clearance was much faster than that of the furniture workers, whose clearance rates were so slow that a group rate could not be derived. Cytologic examinations of nasal mucosa from the furniture workers suggested some abnormalities, including squamous and metaplastic cells in four of the subjects. The referents' nasal cytology was not examined (9).

Andersen et al (3) studied mucociliary transport, respiratory function, and symptomology in 68 Danish hardwood furniture workers from eight plants. Nasal clearance was measured by the placement of a bluestained particle $(0.5 \mathrm{~mm})$ of saccharin on the surface of the inferior turbinate. The subjects were instructed to report when a sweet taste occurred, and this occurrence was verified by the appearance of bluecolored mucus in the oropharynx. On the basis of the levels of wood dust in the breathing zones of the workers, the group was divided into those exposed to dust concentrations of $>5 \mathrm{mg} / \mathrm{m}^{3}$ and those exposed to $<5 \mathrm{mg} / \mathrm{m}^{3}$. Middle-ear inflammation, sinusitis, prolonged colds, asthma attacks, bloody noses, and rhinitis were more prevalent among those exposed to dust concentrations of $>5 \mathrm{mg} / \mathrm{m}^{3}$. There were two modal points in the distribution of nasal transit time, at $14 \mathrm{~min}$ and at 40 or more minutes, the latter group being defined as mucostatic. The authors examined five mean levels of wood dust ranging from 2.2 to $25.5 \mathrm{mg}$ / $\mathrm{m}^{3}$, and there was a striking dose-response gradient observed for the proportion with mucostasis. At the highest level, $63 \%$, compared to $11 \%$ at the lowest level, had mucostasis (3).

Boysen \& Solberg (12) collected nasal biopsies from 113 Norwegian furniture workers and 54 referents. Histological samples were scored blindly for levels of dysplasia and analyzed with linear regression. Hyperplastic rhinitis, nasal stenosis, and allergies were two to four times more common among the furniture workers. Sixteen percent of the variance in the histological scores was explained by the presence of nasal stenosis and the number of years employed in the furniture industry $(P<0.001)$.

The nasal histology of woodworkers with and without nasal cancer was studied in two related studies $(72,73)$ from Sweden. Forty-five veteran furniture workers and 17 staff members from a department of otolaryngology received a histological examination of the mucosa of the middle nasal turbinate [the site where nasal tumors arise in exposed furniture workers (1)]. The workers had been employed an average of 15 years, and they had a mean wood dust exposure level of $2.0 \mathrm{mg} / \mathrm{m}^{3}$. (Species of woods were not given.) The exposed workers had increased cuboidal metaplasia $(\mathrm{P}<0.05)$, and the referents had greater columnar and ciliated epithelia than the exposed subjects $(\mathrm{P}<0.05)$; but there was no correlation between the rhinoscopic and histological findings (73). Wilhelmsson et al (72) reviewed 22 patients who had ethmoidal adenocarcinoma and who had been exposed to wood dust for 18 to 55 years. They determined whether or not the adjacent nonmalignant tissues contained cuboidal metaplasia (72). The results indicated that 19 of $22(80 \%)$ cases had cuboidal metaplasia and 16 of $22(69 \%)$ cases also had dysplasia, although contrast with a reference group (such as chronic pharyngitis patients) would have made the findings more compelling. On the basis of these two studies, the investigators hypothesized that wood dust produces the following sequence of histological changes paralleling mucostasis: loss of cilia and hyperplasia of the goblet cells, initiation of cuboidal cell metaplasia, followed (after a quiescent period) by squamous cell metaplasia. After decades, cellular aplasia leads to adenocarcinoma of the nasal sinuses (73).

All five of the reviewed studies suggest that rhinitis and nasal dysplasia are common among veteran European furniture workers. Given the dose-response association for dust levels (3) and the relation between cuboidal metaplasia and ethmoidal adenocarcinoma $(72,73)$, nasal symptoms and cytological examinations (especially for those with mucostasis) need to be included in any comprehensive health survey of woodworkers.

\section{Discussion of confounding and other biases}

In any evaluation of the association between exposure to wood dust and the risk of respiratory disease, confounding factors must be addressed. Confounding factors are variables that, in a given study, are associated with both the exposure and the disease and also pose an independent risk of disease. Confounding should not be confused with effect modification where the presence of a third factor alters the association between exposure and disease but not at all the exposure strata. (An example might be slowed particle clearance from the nasal mucosa of heavy smokers but not from that of light or nonsmokers.) Leaving confounding variables unadjusted will lead to a spurious assessment of the strength of any association between wood dust exposure and respiratory disease. For end points such as reduced pulmonary function $\left(\mathrm{FEV}_{1.0}\right.$, FVC, and MMF), symptoms of respiratory illness (cough, phlegm, rhinitis, shortness of breath), and effects on normal respiration (impaired nasal clearance 
or asthmatic attacks), confounding variables may include age, sex, and smoking $(40,53)$. Height may also be a confounder for pulmonary function, but sex is a surrogate for this factor, and, because most of the findings in this literature review have been reported for men, they are unlikely to have been confounded by gender.

Age is highly correlated with the amount of work experience and thus with the level and duration of exposure to wood dust. Advancing age also increases the risk of respiratory disease (57). Many of the case studies focused on veteran workers, but their responses occurred after many disease-free years of work with wood dust. Veteran workers must be viewed as a selected, resistant, and surviving population. That is, their reactivity appears only after other more sensitive workers leave employment because they could not tolerate the work conditions [as shown by the asthma prevalence among ex-cedar workers (21)] or because wood dust affected their health or because economic rewards were higher elsewhere. Thus reported risks in cross-sectional studies are likely to be underestimates of the respiratory hazards from current exposure to wood dusts.

Cigarette smoking is a powerful confounding factor because it affects not only the whole respiratory tract, but also other organs and tissues as well $(27,69)$, and has been shown in some studies of byssinosis (52) to be highly correlated with employment in dusty jobs. Cigarette smoking was overlooked in some early case studies, but later epidemiologic research appeared to be cognizant of its influence. Smoking also has the capability to interact synergistically with occupational dust exposures to produce a greater disease effect than two exposures separately $(36,52)$. It is worth noting that woodworkers, like workers in other occupations characterized by high levels of particulate exposure such as coal mining and grain handling, are forbidden to smoke on the job because of the fire and explosion hazard. Thus smoking woodworkers may consume fewer cigarettes than other industrial workers ${ }^{5}$ (29), and therefore confounding or effect modification by smoking may not be as great as for other hazardous occupations such as the installation of asbestos insulation (65).

Acute health effects such as change in pulmonary function during a shift are less affected by confounding from sex, lifetime smoking histories, or other factors; however current smoking must be evaluated (40).

There are other possible sources of confounding, including current or past exposure to hazardous materials (such as asbestos, silica, cotton dust, and coal dust), personal or familial history of allergies, drinking of alcoholic beverages (6) (which is often closely linked to smoking), and additional exposures during work and

5 Smoking prohibition on the job may also increase oral tobacco use and heavier smoking during leisure time to "make up" for the lack of nicotine intake during workhours; these habits are liable to differ between cultures. leisure time (formaldehyde glues, radiation, refinishing work as a hobby). All of these factors may affect respiratory symptoms and pulmonary response to wood dust but may not be strong enough to bias the results. Furthermore, these possible confounders may not have been measurable or were not surveyed in the reviewed studies.

Biases in the measurement of either wood dust exposure or the classification of respiratory disease may also influence the estimation of risk. Sackett (63) presented an inventory of potential biases that led to either an under- or overestimate of the true risk of disease. Possible biases that might be relevant to studies of wood dust and respiratory disease include selection bias in the reference or exposure group (recall that, in reference 21,82 of 203 or $27 \%$ of the reference group of noncedar-mill workers were actually ex-cedar workers); interviewer bias (a possible problem in reference 3 , where symptoms were elicited by the interviewers without a standardized questionnaire); diagnostic bias (reference 51 seemed to draw conclusions on skin testing from 60 asthma patients, more that half of whom did not have occupational responses); and misclassification of exposure [reference 2 assumed inappropriately that all furniture workers were exposed to wood dust (some worked in finishing) and that the referents were unexposed to particulates at an idle power plant]. Misclassification was also likely in references 14 and 33, in which in-plant migration between the planing and shake mills was not examined. Gandevia (37) thought there was misclassification of both exposure and impaired pulmonary function. Because the biases (such as misclassification of exposure) are unlikely to be equal between case and comparison groups, the direction of the risk measures (towards or away from the null value) is unknown; however, lack of a complete follow-up of worker cohorts due to selection is likely to underestimate the real risk of respiratory conditions (63).

Low study power hampers the interpretation of both reference 40 and reference 71 , and all case studies lacking a reference group inhibit the drawing of unbiased conclusions regarding the respiratory toxicity of many types of wood. Identification of type of wood by botanical name was not done in some studies (17, 62,66 ), nor were there adequate dust samples obtained in reference 40 .

In conclusion case studies of many rare and exotic woods (abiruana, cedar of Lebanon, "Congo hardwood", kejatt, mahogany, ramin) suggest that exposed workers respond with eye, nose, and chest irritation. Extracts of some of these woods have also produced positive wheals when skin patch tests were done, but no response was seen for mahogany, oak, or cedar of Lebanon. Despite the variety of woods producing dermatoses (75), positive correlations 
between respiratory effects and skin patch testing need to be better established.

Extensive studies have been done on a clearly defined asthma syndrome produced by exposure to western red cedar (Thuja plicata). Plicatic acid was discovered by Chan-Yeung and her co-workers $(18,23)$ to be the etiologic agent in this syndrome. The western red cedar asthma syndrome includes rhinitis, conjunctivitis, wheezing, cough, and nocturnal attacks of breathlessness characterized by a precipitous decline in $\mathrm{FEV}_{1.0}$ (the measure used in most studies) regardless of smoking status. Skin patch tests are not effective in the clinical diagnosis of the response to this wood dust.

Other commonly used woods such as oak, beech, redwood, pine, teak, alder, and hemlock produce pulmonary effects that are less well-described than the asthmatic responses to western red cedar. These symptoms include bronchitis, loss of pulmonary function during the workday or when exposed, and nasal mucociliary stasis. Nasal obstruction showed exposurerelated findings for concentrations of wood dust in a Danish study of the furniture industry (3) and cuboidal metaplasia may be a precursor lesion for adenocarcinoma of the nasal turbinates $(72,73)$. There appears to be some evidence that smoking may exacerbate the risk of respiratory disease among woodworkers and that those exposed to high concentrations of wood dust have an increased risk of several pulmonary symptoms.

Wood dusts are composed mostly of lignin, hemicellulose, and cellulose, which by themselves and in small quantities (such as that produced by hobbyists) are not mutagenic or toxic (56). The presence of alkaloids, acids, and other natural constituents (which give color and grain to the timber) produces the pulmonary sensitivity. However, it is also likely that decades of exposure to fine wood dust also produces tissue injury that eventually initiates mucostasis and metaplasia and leads to adenocarcinoma of the nasal sinuses. In the light of respiratory cancer excesses among some woodworkers $(1,40,49)$, pulmonary injury or symptoms should be examined as predictors of neoplasia. New surveys of woodworkers need to be done to estimate the prevalence of these health effects in active and retired workers. Because of existing risks for asthma, nasal cancer, and other respiratory conditions, there is need to improve the toxicity testing of woods and their constituents to elucidate the toxic properties better; particularly needed is improved hygienic sampling to examine dose-related responses and to assess interactive effects of combinations of dusts and finishes or adhesives.

\section{Acknowledgments}

This study was supported by grant no RO1 OH0099001 from the National Institute for Occupational Safety and Health.
The authors are grateful to Mr C Baty and Ms D Hicks for typing this manuscript.

\section{References}

1. Acheson ED. Nasal cancer in the furniture and boot and shoe manufacturing industries. Prev Med 5 (1976) 295-315

2. Al Zuhair YS, Whitaker CJ, Cinkotai FF. Ventilatory function in workers exposed to tea and wood dust. $\mathrm{Br}$ $\mathrm{J}$ Ind Med 38 (1981) 339-345.

3. Andersen HC, Andersen I, Solgaard J. Nasal cancers, symptoms and upper airway function in woodworkers. Br J Ind Med 34 (1977) 201-207.

4. Ashley MJ, Corey P, Chan-Yeung M, MacLean L, Maledy H, Grzybowski S. A respiratory survey of cedar mill workers: II Influence of work-related and host factors on the prevalence of symptoms and pulmonary function abnormalities. J Occup Med 20 (1978) 323332.

5. Avila R, Lacey $\mathbf{J}$. The role of Penicillium frequentans in suberosis (respiratory disease in workers in the cork industry). Clin Allergy 4 (1974) 109-117.

6. Banner AS. Pulmonary function in chronic alcoholism. Am Rev Respir Dis 108 (1973) 851-857.

7. Beckman AE, Ashikaga T, Whitehead L. Respiratory dysfunction and occupational wood dust exposure. Presented at the American Statistical Association Meeting, Houston, Texas, August 1980.

8. Belin L. Clinical and immunological data on "wood trimmer's disease" in Sweden. Eur J Respir Dis 61 (1980): suppl 107, 169-176.

9. Black A, Evans JC, Hadfield EH, Macbeth RG, Morgan A, Walsh M. Impairment of nasal mucociliary clearance in woodworkers in the furniture industry. $\mathrm{Br} \mathrm{J}$ Ind Med 31 (1974) 10-17.

10. Blainey AD, Graham VAL, Phillips MJ, Davies RJ. Respiratory tract reactions to western red cedar. Hum Toxicol 1 (1981) 41-51.

11. Booth BH, LeFoldt RH, Moffitt EM. Wood dust hypersensitivity. J Allergy Clin Immunol 57 (1976) 352-357.

12. Boysen M, Solberg LA. Changes in the nasal mucosa of furniture workers-A pilot study. Scand J Work Environ Health 8 (1982) 273-282.

13. Bridge JC. Reports of the Chief Inspector of Factories and Workshops. His Majesty's Stationery Office, London 1937.

14. Brooks SM, Edwards JJ, Apol A, Edwards FH. An epidemiologic study of workers exposed to western red cedar and other wood dusts. Chest 80 (1981): suppl, 30S-32S.

15. Bush RK, Clayton D. Asthma due to Central American walnut (Juglans olanchana) dust. Clin Allergy 13 (1983) 389-394.

16. Bush RK, Yunginger JW, Reed CE. Asthma due to African zebrawood (Microberlinia) dust. Am Rev Respir Dis 117 (1978) 601-603.

17. Carosso A, Ruffino C, Bugiani M. Respiratory diseases in wood workers. Br J Ind Med 44 (1987) 53-56.

18. Chan-Yeung M. Maximal expiratory flow and airway resistance during induced bronchoconstriction in patients with asthma due to western red cedar (Thuja plicata). Am Rev Respir Dis 108 (1973) 1103-1110.

19. Chan-Yeung M. Fate of occupational asthma: A followup study of patients with occupational asthma due to western red cedar (Thuja plicata). Am Rev Respir Dis 116 (1977) 1023-1029.

20. Chan-Yeung M, Abboud R. Occupational asthma due to California redwood (Sequoia sempervirens) dusts. Am Rev Respir Dis 114 (1976) 1027-1031. 
21. Chan-Yeung M, Ashley MJ, Corey P, Willson G, Dorken E, Grzybowski S. A respiratory survey of cedar mill workers: I Prevalence of symptoms and pulmonary function abnormalities. J Occup Med 20 (1978) 323327.

22. Chan-Yeung M, Barton GM, MacLean L, Grzybowski S. Bronchial reactions to western red cedar (Thuja plicata). Can Med Assoc J 105 (1971) 56-58, 61.

23. Chan-Yeung $M$, Barton GM, MacLean L, Grzybowski $\mathrm{S}$. Occupational asthma and rhinitis due to western red cedar (Thuja plicata). Am Rev Respir Dis 108 (1973) 1094-1102.

24. Chan-Yeung M, MacLean L, Paggiaro PL. Follow-up study of 232 patients with occupational asthma caused by western red cedar (Thuja plicata) J Allergy Clin Immunol 79 (1987) 792-796.

25. Cockcroft DW, Cotton DJ, Mink JT. Nonspecific bronchial hyperreactivity after exposure to western red cedar. Am Rev Respir Dis 119 (1979) 505-510.

26. Cockcroft DW, Hoeppner VH, Werner GD. Recurrent nocturnal asthma after bronchoprovocation with western red cedar sawdust: Association with acute increase in non-allergic bronchial responsiveness. Clin Allergy 14 (1984) $61-68$.

27. Cohen BH. Is pulmonary dysfunction the common denominator for the multiple effects of cigarette smoking? Lancet 2 (1978) 1024-1027.

28. Cohen HI, Merigan TC, Kosek JC, Eldridge F. Sequiosis: A granulomatous pneumonitis associated with redwood sawdust inhalation. Am J Med 43 (1967) $785-794$

29. Covey LS, Wynder EL. Smoking habits and occupational status. J Occup Med 23 (1981) 537-542.

30. Doig AT. Other lung diseases due to dust. Postgrad Med J 25 (1949) 639-649.

31. doPico GA. Asthma due to dust from redwood (Sequoia sempervirens). Chest 73 (1978) 424-425.

32. Eaton KK. Respiratory allergy to exotic wood dust. Clin Allergy 3 (1973) 307-310

33. Edwards J, Brooks SM, Henderson F, Apol AG. Health hazard determination report no 76-79, 80, Weyerhaeuser Co, Longview, WA, December 1976. US Department of Health, Education and Welfare, Center for Disease Control, National Institute for Occupational Safety and Health, Cincinnati, OH 1980.

34. Emmanuel DA, Wenzel FJ, Lawton BR. Pneumonitis due to Cryptostroma corticale (maple-bark disease). N Engl J Med 274 (1966) 1413-1418.

35. Evans E, Nicholls PJ. Histamine release by Western red cedar (Thuja plicata) from lung tissue in vitro. $\mathrm{Br} \mathrm{J}$ Ind Med 31 (1974) 28-30.

36. Gamble JF, McMichael AJ, Williams T, Battigelli M. Respiratory function and symptoms: An environmentalepidemiological study of rubber workers exposed to phenol-formaldehyde type resin. Am Ind Hyg Assoc J 37 (1976) 499-513.

37. Gandevia B. Ventilatory capacity during exposure to western red cedar. Arch Environ Health 20 (1970) $59-63$.

38. Gandevia B, Milne J. Occupational asthma and rhinitis due to Western red cedar (Thuja plicata), with special reference to bronchial reactivity. Br J Ind Med 27 (1970) $235-244$

39. Girard JP, Surber R, Guberan E. Allergic manifestations due to wood dusts. In: Frazier CA, ed. Occupational asthma. Von Nostrand Reinhold, New York, NY 1980, pp 91-101.

40. Goldsmith DF. Respiratory disease in the North Carolina furniture industry: A pilot study. University of North Carolina, Chapel Hill, NC 1983 \& University Microfilms, Ann Arbor, MI 1984. (Doctoral dissertation).

41. Greenberg M. Respiratory symptoms following brief exposure to cedar of Lebanon (Cedra libani) dust. Clin Allergy 2 (1972) 219-224.

42. Greene JG, Treuhaft MW, Arusell RM. Hypersensitivity pneumonitis due to Saccharomonospora virdis diagnosed by inhalation challenge. Ann Allergy 47 (1981) 449-452.

43. Hamilton RD, Crockett AJ, Ruffin RE, Alpers JH Bronchial reactivity in Western red cedar induced asthma. Aust N Z J Med 9 (1979) 417-419.

44. Hausen BM. Woods injurious to human health. Walter de Gruyter, New York, NY 1981.

45. Hedenstierna G, Alexandersson R, Wimander K, Rosen G. Exposure to terpenes: Effects on pulmonary function. Int Arch Occup Environ Health 51 (1983) 191198.

46. Hinojosa M, Losada E, Moneo I, Dominguez J, Carrillo T, Sanchez-Cano M. Occupational asthma caused by African maple (obeche) and ramin: Evidence of cross reactivity between these two woods. Clin Allergy 16 (1986) 145-153.

47. Hinojosa M, Moneo I, Dominguez J, Delgado E, Losada E, Alcover R. Asthma caused by African maple (Triplochiton scleroxylon) wood dust. J Allergy Clin Immunol 74 (1984) 782-786.

48. Howie AD, Boyd G, Moran F. Pulmonary hypersensitivity to Ramin (Gonystylus bancanus). Thorax 31 (1976) 585-587.

49. International Agency for Research on Cancer. Wood, leather, and some associated industries. Lyon 1981. (IARC Monographs on the evaluation of the carcinogenic risk of chemicals to humans, volume 25).

50. Innocenti A, Angotzi G. Asma professionale da sensibilizzazione a Triplochiton scleroxylon (samba, obeche). Med Lav 71 (1980) 251-254.

51. Ishizaki $\mathrm{T}$, Shida $\mathrm{T}$, Miyamoto $\mathrm{T}$, Matsumara $\mathrm{Y}$, Mizuno K, Tomaru M. Occupational asthma from western red cedar dust (Thuja plicata) in furniture factory workers. J Occup Med 15 (1973) 580-585.

52. Merchant JA, Lumsden JC, Kilburn KH, O'Fallon MW, Ujda JR, Germino VH, Hamilton JD. An industrial study of the biological effects of cotton dust and cigarette smoke exposure. J Occup Med 15 (1973) 212-221.

53. Miller A, Thornton JC. The interpretation of spirometric measurements in epidemiologic surveys. Environ Res 23 (1980) 444-468.

54. Milne J, Gandevia B. Occupational asthma and rhinitis due to western (Canadian) red cedar (Thuja plicata). Med J Aust 2 (1969) 741-744.

55. Mitchell C. Occupational asthma due to western or Canadian red cedar (Thuja plicata). Med J Aust 2 (1970) 233-235.

56. Mohtashamipur E, Norpoth K. Non-mutagenicity of some wood-related compounds in a bacterial/microsome plate incorporation and microsuspension assays. Int Arch Occup Environ Health 54 (1984) 83-90.

57. Morris JF, Edwards ML, Niles NR, Haas H, Ritzmann LW, Hall C, Tuhy JE. Chronic obstructive pulmonary disease. Fifth edition. American Lung Association, New York, NY 1977.

58. Mue S, Ise T, Ono Y, Akasaka K. A study of Western red cedar-induced asthma. Ann Allergy 34 (1975) $296-304$.

59. Ordman D. Bronchial asthma caused by the inhalation of wood dust. Ann Allergy 7 (1949) 492-496, 505.

60. Paggiaro PL, Cantalupi R, Filieri M, Loi AM, Parlanti $A$, Toma $G$, Baschieri $\mathrm{L}$. Bronchial asthma due to inhaled wood dust: Tanganyika aningre. Clin Allergy 111 (1981) 605-610.

61. Pickering CAC, Batten JC, Pepys J. Asthma due to inhaled wood dusts - Western red cedar and Iroko. Clin Allergy 2 (1972) 213-218.

62. Pimentel JC, Avila R. Respiratory disease in cork workers ("suberosis"). Thorax 28 (1973) 409-423. 
63. Sackett DL. Bias in analytic research. J Chronic Dis 32 (1979) $51-63$.

64. Schweisheimer W. Wood dust and respiratory diseases. Wood 17 (1952) 181.

65. Selikoff IJ, Hammond EC, Churg J. Asbestos exposure, smoking, and neoplasia. J Am Med Assoc 204 (1968) $104-110$.

66. Sosman AJ, Schlueter DP, Fink JN, Barboriak JJ. Hypersensitivity to wood dust. N Engl J Med 281 (1969) 977-980.

67. Terho EO, Husman K, Kotimaa M, Sjöblom T. Extrinsic allergic alveolitis in a sawmill worker: A case report. Scand J Work Environ Health 6 (1980) 153-157.

68. US Department of Health and Human Services, Public Health Service, Centers of Disease Control, National Institute for Occupational Safety and Health. Health effects of exposure to wood dust: A summary of the literature. Cincinnati, OH 1987.

69. US Department of Health, Education, and Welfare, Public Health Service, Office of Assistant Secretary for Health, Office of Smoking and Health. Smoking and health, a report of the Surgeon General. US Government Printing Office, Washington DC, 1979. (DHEW publication no (PHS) 79-50066).

70. van Assendelft AHW, Raitio M, Turkia V. Fuel chip- induced hypersensitivity pneumonitis caused by Penicillium species. Chest 87 (1985) 394-396.

71. Whitehead LW, Ashikaga T, Vacek P. Pulmonary function status of workers exposed to hardwood or pine dust. Am Ind Hyg Assoc J 42 (1981) 178-186.

72. Wilhelmsson B, Hellquist $\mathrm{H}$, Olofsson J, Klintenberg C. Nasal cuboidal metaplasia with dysplasia: Precursor to adenocarcinoma in wood-dust exposed workers. Acta Oto-laryngol 99 (1985) 641 -648.

73. Wilhelmsson B, Lundh B. Nasal epithelium in woodworkers in the furniture industry: A histological and cytological study. Acta Oto-laryngol 98 (1984) 321-334.

74. Wolowicki J. Suberosis (cork pneumoconiosis). In: Proceedings of the IVth international pneumoconiosis conference. Apimondia, Bucharest 1972, pp 536-541.

75. Woods B, Calnan CD. Toxic woods. Br J Dermatol 94 (1976): suppl 13, 1-97.

76. Yasue Y. Asthma due to Western red cedar. Translated from Japanese by Multilingual Services Division, Department of the Secretary of State, Translation Bureau, Ottawa, Canada, Aug 20, 1973. (Original appeared in Mokuzai Kogyo 28 (1973)).

Received for publication: 5 January 1987 